\section{Recent Developments in Rural and Distance Education in New Zealand and their Implications}

\author{
KEN STEVENS
}

$\mathrm{N}$

ew Zealand is one of the most geographically isolated countries in the world and has one of the smallest populations of any of the western democracies, much of it scattered over a variety of remote locations. In this isolated country, rural, and more recently, distance education have made important contributions to the development of the national way of life. Although rural and distance education do not serve the same functions in New Zealand society, each provides a service to people who, for a variety of reasons, mostly relating to the location of their homes, cannot attend schools in major centres on a daily basis.

In the recent past, small schools, most of which are located in rural areas, have been reviewed in New Zealand as has one of the country's most prominent distance education institutions, the Correspondence School. Accordingly, the 1991 Report of the Economic and Educational Viability of Small Schools Review and the recent Review of the Correspondence School form the basis of this survey of recent developments in rural and distance education in New Zealand.

\section{Rural Education}

New Zealand rural education in 1991 was particularly influenced by the publication of the Report of the Economic and Educational Viability of Small Schools Review which, while not devoted entirely to the rural sector of the country's education system, was in large part concerned with the educational viability of small schools in isolated communities. In New Zealand, most small schools are in rural areas, although there are some notable urban exceptions. This article will deal only with that part of the report covering rural education.

The review took place amid considerable media speculation and growing apprehension about the future of small schools in this country. The terms of reference developed by the review team included both economic and social considerations:

- definition of the terms "small" and "viability";

- the identification of the key factors affecting the economic and educational viability of small schools;

- identification of areas of conflict between educational, economic and social criteria that need to be taken into account in determining the viability of small schools;

- outlining of solutions where small schools were not considered to be viable;

- consideration of the implications required by the solutions (e.g., legal, industrial, property, community, transport);

- identification of the general implications of changes which could arise out of this review in relation to other education policies or wider government objectives;

- making of recommendations with regard to:

(i) criteria and processes for determining the viability of individual small schools for establishment, closure or restructuring;

(ii) options for action when schools are found to be non-viable;

(iii) processes for deciding upon and implementing options for action.

The review team began work on 14 January 1991 and was required to complete its task no later than 31 March of that year. Over two thousand letters and submissions were received from throughout the country and, in addition, officials connected with reviews in New South Wales, Tasmania and South Australia were consulted. The review process was therefore completed in a very short time. Its findings have implications for the future of many rural New Zealand communities. Four aspects of small schools were considered: their educational viability, their economic viability, their relationships with their communities, and a number of "associated issues".

The "educational viability" of a small school, as with any school, is difficult to establish. The report defined a small school as educationally 
viable "if pupils in it are taught an appropriate curriculum to a reasonable standard in an environment which enhances achievement and social development." An appropriate curriculum was "one which follows the official syllabuses and associated guidelines developed by the Department of Education before 1 October 1989 and the Ministry of Education since 1 October 1989." Of particular importance were the range and the depth of the curriculum and the professional development of teachers. It was pointed out that secondary level pupils in rural schools might lack the range of subject areas available to their urban counterparts despite the availability of distance education (emphasis mine). The implications of the relationship between rural and distance education could have been further explored in the report, particularly in view of the increasingly sophisticated technologies that are becoming available to distance educators.

Related to this issue is the matter of the professional development of teachers in rural schools, and the report noted that "isolation in itself does not mean that teachers in small rural schools are less capable of delivering the curriculum." While there was recognition that many rural teachers went to considerable lengths to remain up to date by attending courses, the role that distance education could play in this aspect of small rural schools in New Zealand was not fully discussed or explored.

The report noted that there is no New Zealand research on the relationship between school size and educational effectiveness and so overseas material was examined (Wilson and Corcoran,1988; Creemers, Peters and Reynolds, 1989). The report pointed out that "it has yet to be demonstrated that pupil achievement suffers because of the size of a school" in spite of the acknowledgment that it is often thought that rural pupils "tend to achieve at a lower level than their urban counterparts." This apparent contradiction is a further matter that requires research. The report acknowledged the popular belief that smallness in itself may seem an undesirable characteristic in a school to many people, but pointed to research that suggests such an idea is unfounded in relation to small rural schools overseas (Bell and Sigsworth, 1987).

Difficulty was experienced deciding what was meant by educational effectiveness in relation to small schools. The review team decided that lack of New Zealand research made it impossible to reach a conclusion on this matter.
The economic viability of small schools, it was argued, depended on the level of resources that a government was prepared to use to "purchase educational services from schools." In determining the economic viability of small schools, the report noted that there are no published reports addressing the issue of whether economies of scale exist in New Zealand schools, but that "it is assumed in the funding formula for operational grants that economies of scale do exist." It was pointed out however, that:

Population density in large part influences the size of schools; consequently, accepting that a school is required in an area of low population density usually means that the costs involved will be higher than in a more densely populated area (Report, p. 25)

Salaries are the major cost component of any school, typically comprising between $65 \%$ and $80 \%$ of all money spent in a year. Staffing schedules are therefore particularly significant as a unit of school costs in small schools. The review team considered two other items to be particularly significant, however, in the case of small schools: transport and property. It was pointed out that the economic viability of small schools had to be considered in relation to the alternative of transporting pupils to other centres or educating them through the Correspondence School. The issue of pupil transport is complex and is influenced by a range of factors and the report found it impossible to generalise on this matter.

Where a small school has a falling roll, the issue of property maintenance may have to be looked at closely as well as the more general issue of whether there is sufficient utilisation of a public asset to justify its continued existence.

The report considered the particular importance of the relationship small schools have traditionally had with their communities and noted Tomorrow's Schools' endorsement of involvement and partnership in this respect. Social, economic and "symbolic" functions of school-community relationships were outlined. The report observed that closure of a school threatened the well-being and even the continued existence of some small communities as demonstrated by Scottish research which suggests "almost a fifth of the gross current expenditure on a rural school makes a contribution to the community surrounding the school" (Bell and 
Sigsworth, op cit.). The report acknowledged that special consideration should be given to Kura Kaupapa Maori schools, to integrated schools, special schools and "designated character schools". A major issue to emerge from the review in addition to its consideration of educational, economic and community relationship matters, was conflict between availability and choice:

It is important to note that at present the Education Act 1989 provides the entitlement to free enrolment and free education at any state school. This entitlement creates obligations on the institutions and on the system as those with the entitlement exercise their choice.

There is a tension between choice and entitlement (Report, p. 32).

The report acknowledged that choice in rural communities was a "special case" which could be constrained by location and family resources (ibid, p. 32). It would be useful to know more about the nature and extent of this aspect of rural education in New Zealand.

Where a small school was considered to be "non-viable" a variety of "alternative possibilities" were outlined: amalgamation (or merging) with another institution, consolidation with other schools, closure, relocation of the school to another site, use of the Correspondence School and increasing transport and boarding assistance to enable pupils to attend schools in other communities.

The review team formulated seven recommendations for the Government's consideration of the economic and educational viability of small schools:

1. That the "real" and the average per pupil costs of the different school types be identified, the impact of the policy outcomes from other recent reviews on the viability of small schools be determined and schools be encouraged to identify the scale and the location of their excess capacity and suggest uses for their unwanted assets;

2. That a widely constituted group including representatives from the Ministry of Education, School Trustees Association, teacher unions and communities be set up to develop guidelines, based on the report, for the rationalisation of educational provision;
3. That the same process used to disestablish or restructure schools be used for the establishment of new schools;

4. That the process used for examining the provision of education in any area be undertaken at local level, with each district making the initial identification of schools considered non-viable;

5. That any examination of the viability of schools in rural areas take note of the contribution of their communities to the overall life of New Zealand;

6. That community forums, as specified in the Education Amendment Act 1989, be re-examined to make them work more efficiently and less divisively within communities;

7. That the provision of senior secondary schools in New Zealand (particularly in rural areas) be reassessed with a view to developing more appropriate and efficient structures for expanding learning and training possibilities.

The report was supportive of small schools in New Zealand in most of its recommendations but did not fully consider the possibilities of new communication technologies for education in rural communities. If its final recommendation is to be adopted, this seems an obvious aspect of education to be investigated in the immediate future.

Underlying the report is a suggestion that small schools may not be viable in economic and educational terms. A problem for rural educators is that small rural schools in New Zealand really have to be differentiated from other types of small schools (such as those located in urban areas) to a greater extent than has been the case in this report. It is difficult to visualise any community being other than angry at the closure of its school, but in rural areas schools have particular social and cultural as well as educational significance. While this is acknowledged by the review team, its consideration of small schools in rural areas along with small schools in other types of communities signals potential difficulties for the continued well-being of rural New Zealanders. The setting out of criteria for the closure of small schools per se on the grounds of their educational and economic viability threatens a vital aspect of rural New Zealand. In rural communities schools are more than educational institutions; they have so many functions in their 
communities that it is impossible to attach economic or educational values to them. In a country with an economy based to a large extent on primary production, the justification for such a threat is difficult to comprehend. Any proposal that small rural schools may be educationally non-viable suggests lack of understanding of the nature of New Zealand society and its economy. New Zealand society and its economic life are both influenced by rural communities and therefore by the education that is provided in them.

Geoff Skene's report for the Wellington Regional Council, Rural School Reform - The Impact of Government Policies on Rural Schools and Rural Communities in the Wellington Region, provides a highly focussed review of rural education. Skene looked at the impact of Tomorrow's Schools on rural education in a particular region and found that in half the communities he surveyed, involvement in the school had increased since these reforms were introduced. Many communities however, were found to be struggling with lack of resources, including finance.

Thirteen of the twenty one schools that responded to Skene's survey had experienced a change of principal since the introduction of Tomorrow's Schools and most indicated that they had difficulty finding relief teachers. In order to make rural teaching more attractive, communities often provided such things as free meat and firewood for teachers and principals. The most widely experienced problems in rural schools were found to be distance from educational resources and advisers and the lack of local "learning opportunities", sports and cultural events and opportunities for children to experience different lifestyles.

Skene emphasised that communication links are central to the quality of rural life and that schools are central to rural communities. It was reported that farm prices dropped when a local school closed and that it became difficult to sell properties when this happened. This research, like the Report of the Economic and Educational Viability of Small Schools Review, emphasised the central community role of rural schools and found that many of them are currently experiencing difficulties with administrative and other changes.

A third recent rural education publication makes some timely observations on a little known aspect of this country's economy. Ken Moore investigated farmer training in New Zealand, which he termed the "Cinderella of the New Zealand education system". Learning on the Farm was the outcome of a survey of one hundred and ten farmers in the South Island over a three month period in 1988 which aimed to discover how they learned to farm and what methods they used to stay up to date with developments in agriculture. Moore directed his questions to the education farmers had received and to their current farming practices to see if any relationship could be discerned in their attitudes to training for farm management.

In a country like New Zealand, these are important questions which link the major national industry and the education system. Moore achieved a 93\% coverage of the farmers that he surveyed, all of whom lived within twenty minutes drive of a Ministry of Agriculture and Fisheries office near Christchurch. In spite of the ready availability of farming and management expertise Moore found few people entered New Zealand farming with any formal training for the job and fewer than one third of the farmers surveyed had ever asked for Ministry of Agriculture advice. Most farmers were found to rely on other farmers for advice and on local knowledge. Willingness to work hard and without supervision was rated far ahead of university qualifications when listing the important characteristics for a farm manager. Farmers, it was found, prefer small and relaxed learning environments in which they can question, discuss and debate rather than university-style lectures. It is not surprising then, that Moore found a direct relationship between the length of schooling farmers received and the extent to which management practices are used, or, more commonly, not used. New Zealand is an exporter of agricultural expertise and it is surprising, therefore, that in a country that relies so heavily on farming for its national income and in which such expertise is readily available, most farmers are little influenced by agricultural education and training.

A major problem in the further education and training of New Zealand farmers that Moore found is the low level of formal education they have received and the difficulties subsequently experienced "at the more symbolic or formal operational stages." For example, many farmers were found to have difficulty with concepts like "kilograms of dry matter".

The challenge is how to find ways to close the gap between scientists (and scientific language) and farmers who are the agricultural 
practitioners. This is basically a problem of communication and Moore concluded his study with several recommendations: that the practical implications of scientific research be fully discussed with farmers in a way that all can understand, that farmers be informed as to where they can find a farmer who has successfully implemented change on the basis of particular scientific information, and that farmers be given information in an environment in which they feel at ease.

The value of this type of educational research for rural communities is difficult to overestimate. The role of the polytechnics in educating the farming community is the subject of some discussion and Moore reached the conclusion that these institutions, practically all of which are located in urban areas, need to "explore ways to better serve rural areas, particularly in the provision of farm related training."

Learning On The Farm concluded with an ominous prediction:

It is likely that farm productivity will drop until a higher proportion of farmers receive better education and training. If this better trained group of farmers fails to emerge, the likely trend will be to fewer, larger farms, managed by essentially business-trained people overseeing a stockman/tractor driver group who provide the manual labour.

The educational implications for rural New Zealand have seldom been outlined in such graphic terms. Unless science, management and farming can communicate more satisfactorily, the future of rural communities is likely to be drastically changed.

\section{Distance Education}

Recently distance education has been the subject of some attention in New Zealand. The Correspondence School, one of the country's best known educational institutions, was reviewed in 1989 and the report has recently been made available to the public. The Correspondence School has several important functions in New Zealand education including the provision of education to people in remote locations; the delivery of courses to pupils attending other secondary schools who cannot have classroom tuition provided on a regular basis because of lack of available staff or lack of numbers to constitute a class; the provision of adult education; and, the provision of second chance education. Many New Zealanders have received their education overseas through the Correspondence School and others have been able to receive lessons at home or while in hospital or prison. The Correspondence School has many functions and meets a wide variety of educational needs in New Zealand.

The background to the review of the Correspondence School is located in the 1989 Government budget in which this institution was asked to make savings of two million dollars in the following financial year. The Review of the Correspondence School should be considered in the context of the major reforms that have recently taken place in the education sector, in particular the changed relationship between the administration of education and the pursuit of wider political and economic goals. As the Correspondence School has always been involved in the provision of education to disadvantaged groups in New Zealand and the education reforms were intended to pursue more equal outcomes across gender, ethnic and other minority group lines, the review of this institution was central to a broad consideration of equity in New Zealand society. The review team was asked to look carefully at the costs of services to part time adult students and to recommend ways of controlling these without disadvantaging people who had no other way of obtaining an education. The review was also required to look at the efficiency of the institution and to consider the Correspondence School in the context of other distance education providers in New Zealand.

The review recommended amending the Education Act (1989) to allow the charging of fees to adult part time students. (This, it was pointed out, should also apply to other learning institutions which cater for adult part time students). It was further recommended that adult part time students be charged for postage, enrolment and tuition fees and that research be undertaken immediately to find out why approximately $75 \%$ of New Zealand secondary schools had made predictable" (i.e., planned) dual enrolments in the Correspondence School over the previous three years. The review team was of the opinion that such dual enrolments should not be an open-ended cost to the Correspondence School; schools making use of the Correspondence School should purchase the service as a client, as should home schoolers and private schools. 
The review team found that the Early Childhood Education section of the Correspondence School had a waiting list for its services. This, the review pointed out, was inconsistent with the Government's policy on the provision of Early Childhood Education for New Zealanders. The review recommended that this section of the Correspondence School negotiate a separate charter with the Ministry of Education which would represent a contract to provide Early Childhood Education to a defined population of children. To enable the Correspondence School to do this an additional grant of $\$ 200,000$ in the following financial year was recommended.

A significant recommendation, finally, was that the Correspondence School become more entrepreneurial. It was pointed out in the review that this institution could generate between $\$ 1.2$ million and $\$ 3.6$ million in revenue from educationally advantaged part time adult students and by acting as a resource to Boards of Trustees and other training and education providers throughout the country.

\section{The Future: Merging Rural and Distance Education}

The field of distance education is growing rapidly and the Review of the Correspondence School goes some way in outlining its possibilities in the immediate future in New Zealand. Tom Prebble (1990) outlined the training needs that are emerging in this specialised but increasingly mainstream aspect of education. Distance education has had a natural affiliation with rural education as both have traditionally provided services to geographically isolated people. As communications improve however, and as more people become aware of the opportunities that can be provided through distance education, it is likely that there will be less consciousness of the geographical dimension of education and concepts like "rural education" will have less significance. In the near future the concept of educational networks, made possible by the combination of various technologies (telephone, video, computer) will become increasingly available to New Zealanders. Some of the advantages of rural education will be shared with other schools and many of the benefits at present enjoyed by urban pupils and teachers will be available to everyone who wants to participate in education and training, regardless of where they live. For example, a school in south Westland could be linked to several other schools, both within and beyond New Zealand and students in this and other geographically isolated parts of the country could participate in classes in Auckland or Singapore or Vancouver. Students could, through electronic networks, access data bases and libraries in other centres, as well as teachers and fellow students, all of which will contribute to a reduction in their isolation and an increase in their participation in the educational community. There are many educational possibilities in contemporary developments in communications technologies for curriculum design, school and inter school organisation and the provision of equality of opportunities.

Developments in communication technologies are likely to have major implications for rural New Zealand communities as well as their schools. The reduction in isolation that new communication technologies can provide, together with the appeal of rural lifestyles could make possible the re-location of some industrial and business activities and perhaps encourage a reversal of rural-urban population migration. At a time when small rural schools are in a position to achieve parity with other schools through advances in communications technologies, it is surprising as well as short-sighted to be even contemplating their closure. As distance education teaching is introduced to increasingly sophisticated communication technologies, rural communities are likely to be transformed along with their schools.

With the imminent possibility of national and even international educational networking, size as well as location will in future have diminishing significance and there will be little to prevent even the smallest school offering an extensive curriculum. The next decade is likely to see a transformation in what at present is known as rural and distance education as non metropolitan communities become less "rural" and education systems become networked and the notion of "distance" becomes, in educational terms, obsolete.

\section{References}

Bell A. and Sigsworth A. The Small Rural Primary School: A Matter of Quality. Philadelphia, Falmer Press, 1987.

Creemers B., Peters T. and Reynolds D. (Eds.), School Effectiveness and School Improvement. Amsterdam, Swets and Zeitlinger, 1989.

Independent Review Team, Review of the Correspondence School. Wellington (mimeo), 1989. 


\section{Ken Stevens}

Report of the Economic and Educational Viability of Small Schools Review. Wellington (mimeo), 1991.

Moore K. Learning On The Farm - The Educational Background and Needs of New Zealand Farmers. Wellington, New Zealand Council for Educational Research, 1990.

Prebble T. "Training in distance education: Policy, planning and management" in Perspectives on Distance Education. Vancouver, Commonwealth of Learning, 1990.

Skene G. Rural School Reform - The Impact of Government Policies on Rural Schools and Rural Communities in the Wellington Region. Wellington, Wellington Regional Council, (mimeo), 1990.

Department of Education, Tomorrow's Schools - The Reform of Educational Administration in New Zealand. Wellington, 1988.

Wilson B. L. and Corcoran T. B. Successful Secondary Schools. London, Falmer Press, 1988.

\section{The author}

Ken Stevens is a Senior Lecturer in Education at Victoria University and was formerly a member of the Faculty of Education at James Cook University of North Queensland. His research interests are in rural, distance and vocational education. 